\title{
Relato de caso: Lúpus eritematoso induzido por Carbamazepina
}

\author{
Matos, R.P.; Moreira, R.M.; Vitorino, J.A.; \\ Apresentador: Renato Piucco Matos
}

\section{Resumo}

Introdução: O Lúpus Eritematoso Sistêmico (LES) é uma afecção autoimune do tecido conjuntivo com amplo espectro de características clínicas, além de significante morbidade e mortalidade. Estima-se que $10 \%$ dos casos sejam induzidos por medicações, tendo-se uma série de drogas que podem causar Lúpus Eritematoso fármaco-induzido (LEFI). Esta patologia é caracterizada por sintomas lúpus-like após a exposição por pelo menos um mês a certas medicações - destacando-se artralgia, mialgias, febre e serosite. O FAN comumente é positivo, porém pode ser negativo. A positividade do anticorpo anti-histona também está relacionada ao LEFI. Neste relato, descreve-se o caso de um paciente do sexo masculino, 60 anos de idade, com início de Carbamazepina há dois anos. Há dois meses iniciou com fotossensibilidade e rash malar, além de aftas orais recorrentes. Há um mês, refere quadro de astenia e mialgia difusa, associado à rigidez matinal e edema de interfalangeanas bilateralmente. Há duas semanas, apresentou dor em hipocôndrio esquerdo e episódio isolado de febre baixa. Foi realizada radiografia de tórax evidenciando derrame pleural à esquerda, sendo encaminhado à internação hospitalar. Ausculta pulmonar com murmúrio reduzido em base pulmonar esquerda, restante do exame físico sem particularidades. Exames laboratoriais dentro dos limites da normalidade, exceto por aumento de Proteína-C reativa (PCR 59). Líquido pleural (LP) com 540 células e predomínio linfocítico (90\%), com lactato desidrogenase (LDH) aumentada. Teste para bacilo ácido-álcool resistente (BAAR) e adenosina deaminase (ADA) no LP negativos. Tomografia computadorizada (TC) de tórax com pequeno derrame pleural à esquerda e discretos sinais de broncopatia, enquanto abdome dentro dos limites da normalidade. Pesquisas de anticorpos contra antígenos celulares (FAN), fator reumatóide, AntiDNA e Anti-Smith (Anti-Sm) foram não reagentes. Apresentou anti-histona positivo em altos títulos. Recebeu alta estável e com resolução do derrame pleural, porém, antes deste resultado. Contudo, não retornou à consulta ambulatorial para seguimento, não sendo possível a suspensão do fármaco - o tratamento preconizado. Assim, mesmo sendo uma síndrome incomum, a possibilidade de LEFI deve ser sempre considerada devido à reversibilidade do quadro e a importância do diagnóstico precoce. Além disso, podemos notar que a falta de critérios diagnósticos padronizados continua sendo um desafio aos médicos na prática clínica.

\section{Referência:}

Matos, R.P.; Moreira, R.M.; Vitorino, J.A.;. Relato de caso: Lúpus eritematoso induzido por Carbamazepina. In: II Congresso Brasileiro de Medicina Hospitalar - II CBMH [= Blucher Medical Proceedings, vol.1, num.5] São Paulo: Editora Blucher, 2014. p.86

DOI 10.5151/medpro-II-cbmh-084 